\title{
Margaret McCartney: Nits—no hiding from head lice
}

\author{
Margaret McCartney general practitioner, Glasgow
}

We are over-run. Our houses are habitats for bacteria, mice, rats, and spiders, as well as humans. Bugs are in our beds, and flies are eyeing the rubbish bins. We are but one species among many, exerting our claim to clean survival with soap, detergent, bleach, and mousetraps.

Letters come from school: there are outbreaks of head lice. Humans and lice go together. The Romans had them. The nit nurse used to visit my primary school, fingering through our locks, dispensing shame and letters home to the infested ones. Now a missive is sent by school bag post, urging parents to check their children and to visit the pharmacy for advice. Take along a louse stuck to sticky tape as proof of its habitat on your offspring's scalp. You will be offered a chemical cure.

I kissed my children's heads at the school gates for 15 years without noticing a single nit. This year, however, my easy game is up. The letters keep coming home, as constant as wasps at a picnic. Check your child. I did so, intermittently, but the hairdresser came over for a discreet word in the salon. I felt horror: but I'm a good mother! Oh, smug, self satisfied me-the one who had, for years, been trailing out lines about head lice not being related to hygiene, suddenly unable to believe my own advice. The fine toothed metal comb was brandished daily, and my youngest adopted the process of "nitillation" as routine. Everything was fine. But then life got in the way. The 10 minutes spent on the sofa tugging through tresses simply slipped off the agenda.

A few months later I noticed my youngest distractedly scratching behind his ear. I went to find the comb. Oh no, not again. I examined the nasty little parasite under a magnifier. I looked at it resentfully. "Nits!" cried my youngest, rebranding his affliction as a battle cry for use in future sibling turf wars. It's okay, I thought, while searching for the bottle of lotion; really, it's nothing to do with poor parenting.

This is normal, I told myself. This is about biology and the coexistence of different species and the eternal grapple for supremacy. And isn't it funny, I mused, how you always start to feel itchy when witnessing someone else's infestation: isn't psychology amazing? But I couldn't quite believe that, either, because when I idly trained the fine toothed comb over my own scalp, inspecting it half heartedly, a live creature reared its tiny legs on the glinting metal, looking as indignant and as found-out as I felt.

Follow Margaret on Twitter, @mgtmccartney

Competing interests: I have read and understood the BMJ policy on declaration of interests and declare the following interests: I'm an NHS GP partner, with income partly dependent on Quality and Outcomes Framework points. I'm a part time undergraduate tutor at the University of Glasgow. I've written two books and earn from broadcast and written freelance journalism. I'm an unpaid patron of Healthwatch. I make a monthly donation to Keep Our NHS Public. I'm a member of Medact. I'm occasionally paid for time, travel, and accommodation to give talks or have locum fees paid to allow me to give talks but never for any drug or public relations company. I was elected to the national council of the Royal College of General Practitioners in 2013 and am chair of its standing group on overdiagnosis. I have invested a small amount of money in a social enterprise, Who Made Your Pants?

Provenance and peer review: Commissioned; not externally peer reviewed.

Cite this as: BMJ 2015;351:h5725

๑) BMJ Publishing Group Ltd 2015 